\title{
Gårdejer Jens Petersen Jensen fra Lovrup og Skoleforeningen
}

\section{af H.E.Sorensen}

I 1992 fylder Den nordslesvigske Skoleforening 100 år. Foreningens første formand var gårdejer J.P. Jensen fra Lovrup. H. E. Sørensen, Skærbæk fortæller her, bl.a. på grundlag af nye kilder i privateje, om J.P.Jensen og hans slagt og om foreningens oprettelse og arbejde.

\section{Peder Jensen}

Onsdag den 30. november 1892 klokken 3 eftermiddag afholdtes på Åblings Hotel i Skærbæk et møde, som fik skelsættende betydning for den kulturelle og politiske udvikling i Sønderjylland. Her stiftedes nemlig Den Nordslesvigske Skoleforening - i dag Sønderjydsk Skoleforening , den yngste af de tre store nationale danske foreninger i Sønderjylland, Vælgerforeningen, Sprogforeningen og altså Skoleforeningen. Ved mødet valgtes gårdejer Jens Petersen Jensen fra Lovrup i Døstrup sogn som formand for foreningen.

Hans slægt var grundfæstet på egnen, og gården havde været i familiens eje fra slutningen af 1400-tallet, altså i henved 400 år. En slægts- og ejertavle, udarbejdet af pastor Jørgensen i Døstrup o. 1908, opregner ejerne. Det første århundrede er rækken lidt usikker, men fra 1599 ligger den klar:

Peter Madtzen (død 1623), gift med Karen Peters (1552-1630). Overtog gården 1599.

Knud Petersen (1587?-1667), gift 1619 med Anna Petersdatter (1590?-1665). Store Peter Knudsen (1627-1700), gift med Mette Jensdatter (1648-1697). Jens Petersen (før 1685-1727), gift med Anna Catharina Pedersdatter (16881757).

Peter Jensen (1718-1777), gift før 1763 i Mjolden med Maren Pedersdatter (1733-1803).

Jens Petersen (1774-1833), gift 1799 med Else Nielsdatter Timmermann (17691840).

Jens Petersens aftægtskontrakt med sønnen Peder Jensen er bevaret. Den er underskrevet d. 5. august 1833:

"Underskrevne Jens Pedersen i Lourup tilstaar hermed at jeg overlader til min Søn, Peder Jensen, den mig tilhørende og her i Lourup Bye beliggende $\frac{1}{2}$ Eiendomsgaard førhen Lindevithe, nu henlagt under Løgumcloster med Bygninger og Jordeiendomme Ind- og Udboe Levende og Dødt intet undtagen $i$ 
nogen Maade, hvorimod han eller sine Efterkommere sikrer mig og min Hustru en bestemt Aarlig Aftægt samt betaler al den med Gaarden hæftende Gjæld.

\section{Aftagt}

1. Bemeldte min Søn Peder Jensen eller Gaardens Eier giver mig og min Hustrue fri Huusning i Gaarden i et velordnet Kammer med Kakelovn og Sengesteder samt Skorsteen for os selv med tilbørlig Kjøkkentøi samt Bryggerog Kogeredskaber og fri Adgang til Brændselsskur. Desuden skal han eller Gaardens Eier forsyne os med fornødne Klæder af Ulden og Linned, holde os en Koe levende og aldrig død frie paa Foder og Græs; naar Koen er seen (gold?), da levere os en kande nymalket Mælk hver Dag og 2 pund Smor hver Uge, hvert Aar levere til os 4 Tdr Rug, $1 \frac{1}{2}$ Tonde Boghved Gryn, $1 \frac{1}{2}$ Tdr Byg Gryn, 2 Tdr Malt, 6 Lispund tørret Flæsk, 6 Lispund Kjød og 100 Rd aarlig i Haandpenge. Desforuden skal Gaardens Besidder yde os den fornødne Pleje og Opvartning i Sygdoms og Alderdoms Tilfalde, samt frie Befordring med Vogn til Kirke, Mølle eller andensteds. Naar een af os ved Døden afgaaer, bortfalde det halve af benæunte Aftægt saavel i Natura som Penge. Naar jeg og min Hustrue træde paa Aftægt, modtager vi 2de fuldstændige Senge, 2 Kister, 2 Borde, 6 Stole samt andet fornødent behøvent Indboe, som alt naar den sidste af os ved Døden afgaaer skal tilfalde Stavnens Beboer. Naar vi ved Døden afgaaer, skal Stavnens Beboer eller Gaardens Eier besørge os en hæderlig og sømmelig Begravelse efter Sognets Skik og Brug.

2. Skulde Omstændigheder indtræffe, at jeg og min Hustrue ei vil blive $i$ Gaarden og modtage Aftægten i Natura, skal det være os tilladt at fløtte hvorhen vi vil, og da skal Gaardens Eier være forpligtet til at betale til os istedet for Aftægten den Sum 100 RDL S.H.C. (Slesvig-Holstensk courant) aarlig, som betales i 4re Terminer. Alligevel skal Gaardens Eier være forpligtede til at besørge os en hæderlig Begravelse efter vor dødelige Afgang, og da skal alt, hvad vi efterlader os tilfalde Gaardens Eier undtagen rede Penge«.

Jens Pedersens underskrift er meget rystende, og det er i hvert fald ikke ham personligt, der har udfærdiget dokumentet, og sandsynligvis heller ikke sønnen, men snarere en tilkaldt notar, som dog ikke har sat sit navn på papiret, hvad han vist efter reglerne skulle have gjort.

Det hele bærer præg af at være sket $i$ hast. Men der har heller ikke været megen tid at spilde. Jens Pedersen døde fire dage senere, den 9. august 1833, mens hustruen, Else Nielsdatter Timmermann, levede endnu godt seks år og døde 10. januar 1840. Samme år, den 5. december 1840, giftede Peder Jensen sig med Caroline Nielsdatter, født i Drengsted 1813, død i Lovrup 1856. 


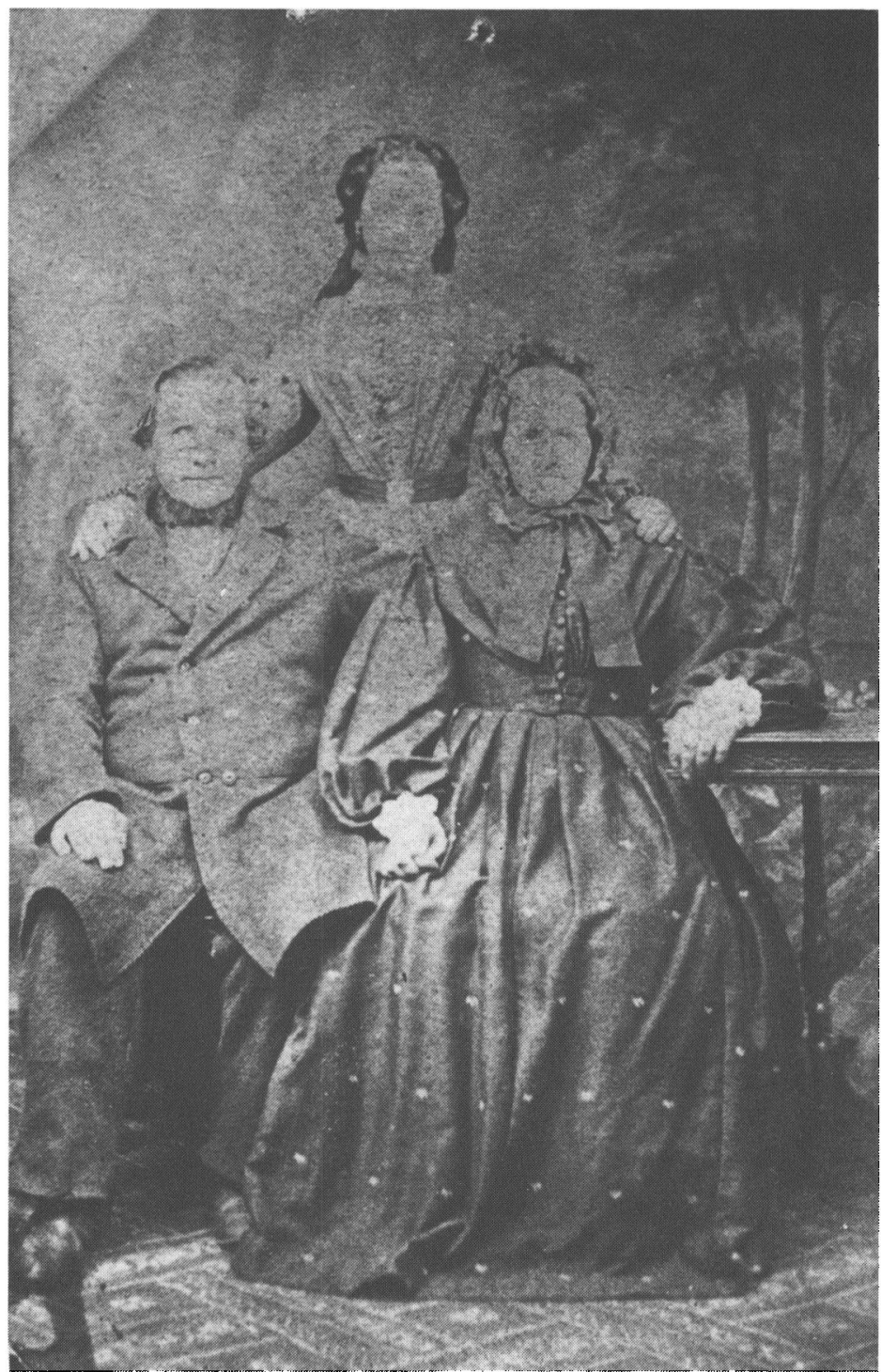

Peder Jensen, d. 1874, med hustru Caroline Nielsdatter, d. 1856 og en ukendt bagest. Foto i Skarbakegnens Museum, vel fra 1850 'erne.

Peder Jensen øgede gårdens tilliggende bl.a. ved jordkøb fra en mand ved navn Werner, ligesom han kom til at spille en betydelig rolle i sognets og egnens liv. Således var han medlem af boniteringskommissionen (vel sagtens 
en slags vurderingskommission, der skulle afgøre jordens værdi efter bonitet, d.v.s. ydeevne - hvor "gode de var«) og af Ribe amtsråd. Døstrup sogn og dermed Lovrup hørte til de kongerigske enklaver og hørte derfor med til Ribe amt i kongeriget og ikke til hertugdømmet.

I et amtsrådsreferat fra 1858 nævnes det, at herredsfoged Sarauw i Visby har indberettet, at »en del af gesimsen i salen i Visby Thinghuus er nedfalden«. Amtsrådet overlader det til herredsfogeden wat foranstalte Istandsættelsen efter foregaaende Conference med Amtsraadsmedlem P. Jensen." Referatet fra amtsrådsmødet er i øvrigt undertegnet af syv medlemmer, heriblandt Peder Jensen.

En artikel i (vistnok) »Jydske Tidende « - desværre udateret - fortæller om en af Jensens planer, sandsynligvis o. 1870, da man diskuterede en sammenlægning af skolerne i Døstrup sogn: „Den kendte gårdejer Peder Jensen fra Lovrup foreslog, at der skulle bygges en sogneskole ved Møldam, der ligger midt imellem Lovrup og Døstrup; men stærke røster talte imod, og et af de stærkeste argumenter var, at børnene fik for langt til skole. Dette vidste Peder Jensen også råd for, idet han foreslog at bygge en smalsporet skinnebane fra byerne til skolen og lade den trække af heste, der den gang var den ypperligste trækkraft, man kendte. Kloge hoveder mente, at disse planer var for storslåede og gik hårdt imod dem. Der opnåedes til sidst enighed om at bygge skolen, der nu er lærerbolig, kaldet den gamle skole« (i Døstrup by).

Peder Jensen var desuden medlem af kirkeforstanderskabet og førte bl.a. kirkens tienderegnskab.

Han døde 26. april 1874 og blev begravet på Døstrup kirkegård. Hans sognefæller satte en sten over ham med den indskrift, at han whavde virket lige så uegennyttigt som nidkært. Han var en god mand « - og smukkere eftermæle kan man vel næppe få.

Ved hans død var der ikke blevet skiftet mellem de tre sønner, men skifteakten, der er udfærdiget i september 1874, fem måneder efter dødsfaldet, lader i al sin korthed intet tilbage at ønske i tydelighed:

\section{"Skifteakt}

Den 26. April d.A. døde vor Fader Peder Jensen, Gaardejer i Lavrup, efterat vor Moder Karoline Jensen, født Nielsen, allerede i Aaret 1856 var afgaaet ved Døden. Deres Arvinger er deres fælles trende underskrevne Sønner, Jens Petersen Jensen, Niels Oksen Jensen og Peter Antonius Jensen.

Da vi alle 3 ere myndige og for Tiden samlede her til stede, have vi efter gjensidig Overenskomst bestemt os til at dele Boet paa følgende Maade. Jeg Jens Petersen Jensen overtager vore afdøde Forældres hele Bo, saa vel Gods 
som Gjæld, uden nogen som helst Undtagelse, navnlig Gaarden i Lavrup med de dertil indkjøbte Parceller og den paa samme første opførte Aftægtsbolig og det af vor Fader ved Kjøbekontrakt med P. Chr. Werner af 15. December 1870 erhvervede, paa Tætvang Mark beliggende Stykke Hedejord med det derpaa opførte Hus, og udbetaler hver af mine 2 Brødre 5000 Rdr d.R.M. (deutsche Reichs Mark) $=3750$ pr. (preussische) som fuldstændig Arveaffindelse efter deres Forældre, hvorfor jeg samtidig herved udstæder dem tilsvarende Gjældsbeviser.

Nærværende Skifteakt tjener vor Broder og Medarving Jens Petersen Jensen tillige som Adkomstbrev paa fornæunte faste Ejendomme. Ovennæunte Deling er foretaget til vor fuldkomne Tilfredshed og underskrive vi til Anerkjendelse heraf samme egenhændig ....

\section{Jens Petersen Jensen}

Jens Petersen Jensen blev født på fædrenegården i Lovrup den 24. februar 1841. Hele sit liv blev han boende dér. Hans skolegang fandt sted i landsbyskolen, og hans store viden skyldtes dels, at han som en opvakt knægt havde øjne og ører åbne, dels at hans far - Peder Jensen - var en mand af store kundskaber, som han lod gå videre til sine tre sønner.

Den 8. oktober 1864 - kort efter krigens afslutning - blev Jens Petersen Jensen gift med datteren på nabogården, Kjersten Marie, født den 13. september 1837 i Sølsted, hvor faderen, Jørgen Wilhelm Petersen, havde en gård, inden han flyttede til Lovrup. Hendes slægt var således ikke hjemmehørende i denne landsby på samme måde som hans egen. Året efter overtog han -24 år gammel - driften af gården, som han altså fik endeligt skøde på efter faderens død i 1874. Af de to brødre blev Peter Antonius Jensen, kaldet Antoni Jensen, en kendt gårdejer i Mejlby. Hvorledes det gik den anden, Niels Ocksen Jensen, ved jeg ikke.

Kjersten Marie og Jens Petersen Jensen fik ti børn, hvoraf tre døtre og tre sønner overlevede faderen. En af dem, Jens Ocksen Jensen (14/3-1884-8/11933) overtog gården, men måtte sælge den i 1926 til Christian Hybschmann (1894-1966), hvis søn, Thomas Hybschmann, født 1926, har den i dag. Jens Ocksen Jensens søn, der hedder Jens Petersen Jensen som bedstefaderen, fødtes 13/9-1911. Han bor i dag i Bov, og det er gennem ham og Th. Hybschmann, at jeg har fået kendskab til gårdens og familiens papirer.

Det unge ægtepar, som i 1865 overtog den gamle gård, sad rimeligt godt $\mathrm{i}$ det. Gården var økonomisk solid og uden større behæftelser, end det var til 


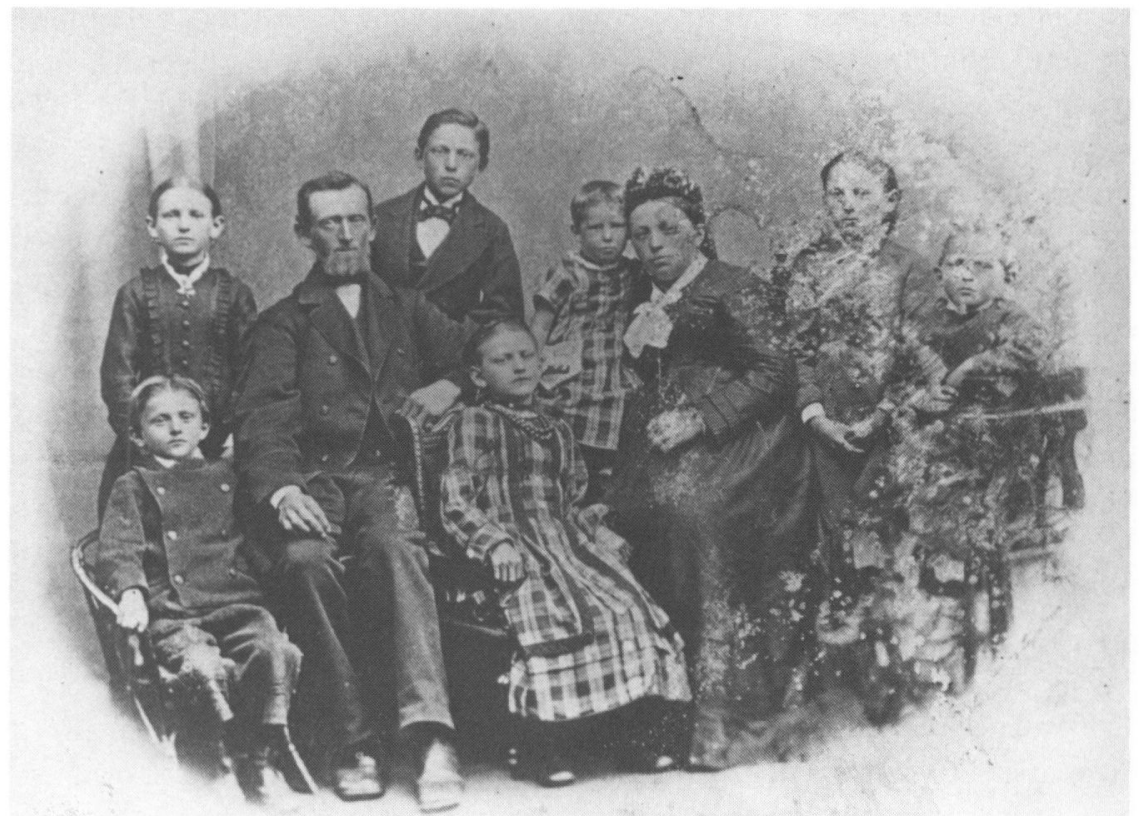

Jens Petersen Jensen med familie. Foto o. 1890 i Skarbakegnens Museum.

at overse. Han var desuden en dygtig og fremsynet landmand, der ikke gik af vejen for at prøve nyt, bl.a. var han en af de første på egnen, der gik i gang med at dyrke roer og anvende kraftfoder til køerne. De andre gårdmænd nøjedes $\mathrm{i}$ begyndelsen med at se til og iagttage Jensens resultater. Men som det ofte sker, var det dyrt at være den første. Jens P. Jensen måtte prøve sig frem, inden resultaterne viste sig positive. Eksperimenterne kostede mange penge og var med til at undergrave hans solide økonomiske position.

Det var ikke unaturligt, at Jens Petersen Jensen fulgte sin lyst og trang som han vel havde efter faderen - til at gå ind i offentligt og politisk arbejde. Han valgtes ind $\mathrm{i}$ Døstrup sogns kirkeforstanderskab (menighedsråd) og $\mathrm{i}$ Nørre Tønder provstisynode (et slags »menighedsråd « for hele provstiet). Det var i de år, hvor de første alvorlige angreb rettedes fra tysk side mod dansk skole- og kirkesprog, og Jens P. Jensen var en af dem, der kraftigst og mest konsekvent satte ind som forsvarer af modersmålets ret $i$ opdragelse og gudstjeneste. Det endte da også med, at han på grund af sit konsekvente danske sindelag blev afskediget af myndighederne som skoleforstander i Døstrup sogn (formand for skolekommissionen), en post, han havde beklædt i ganske mange år. 
I 1880'erne gik han i spidsen for det danske oplysningsarbejde på egnen og fik stiftet Foredragsforeningen for Skærbæk og Omegn, der med ham selv som formand samlede mange til møder og foredrag. Og da samtidig det værste tyske stød mod skolen satte ind med forordningen af 1888, der helt afskaffede undervisning på dansk, bortset fra 2-4 ugentlige religionstimer, var det ikke unaturligt, at Jens P. Jensen også her blev en af de mænd, der tog initiativ til et modstød.

\section{Skoleforeningen}

Tanken om en dansk skoleforening opstod. Ideen kom vistnok oprindelig fra højskoleforstander Søren Hansen Salling, der ledede mejeri- og folkehøjskolen i Ribe. Han var født i Lintrup 1842. Efter lærereksamen havde han først stilling i Aabenraa, senere i Lustrup ved Ribe, inden han blev lærer på forskellige højskoler i kongeriget. 1879-1890 drev han en folkehøjskole på gården Lustrupholm syd for Ribe, hvorefter han omdannede den til en mejeri- og folkehøjskole. Her havde han sit virke til sin død i 1918.

I de samme år oprettedes en hel stribe af høj- og efterskoler umiddelbart nord for den dansk-tyske grænse - i Hejls, Skanderup, Skibelund, Askov, Holsted, Bramminge, Lustruplund og Vester Vedsted , der alle i udpræget grad søgte og fik deres elever fra danske hjem i Sønderjylland. Dette var naturligvis en torn $\mathrm{i}$ øjet på de prøjsiske myndigheder, men det kunne også være svært for forældre at sende deres børn dertil, dels på grund af det prøjsiske tryk, dels af økonomiske grunde.

Salling fik nu den idé at oprette en forening, som dels skulle give moralsk opbakning, dels yde kontante tilskud til sådanne skoleophold. En af de første, han henvendte sig til i Sønderjylland, var netop Jens Petersen Jensen. Han greb ideen med begejstring, og med sine udbredte kontakter over hele landsdelen fik han sammenkaldt til et møde $i$ sit hjem den 7. august 1892 hvor forslaget drøftedes. Efter at Salling havde fremlagt sine tanker i et foredrag, blev det gennemdiskuteret, og de tilstedeværende var enige om at arbejde videre med sagen.

Den 22. oktober sammenkaldtes igen til møde på Jensens gård i Lovrup. Her deltog den unge H.P.Hanssen, der netop $\mathrm{i}$ disse år fremstod som en primus motor $\mathrm{i}$ det danske arbejde i Nordslesvig, samt en lang række kendte vestslesvigske gårdmænd, bl.a. Andreas Thyssen Hansen fra Randerup, Bende Bendesen fra Harres, H.D.Poulsen fra Drengsted og Anders Petersen Lund fra Ballum Rejsby. To af midtlandets kendteste mænd, Hinrich Thomsen fra Roost og Anders Dons Hørlück fra Rurup, havde måttet sende afbud. 
H.P.Hanssen forelagde et udkast til love for den påtænkte forening, og forsamlingen vedtog et opråb, ligeledes udformet af H.P.Hanssen, som opfordrede til at møde frem til det stiftende møde, der skulle finde sted whos gjæstgiver Aabling i Skærbæk onsdagen den 30. november, efterm.kl. 3.«

I opråbet hed det: "Vort modersmål er nu snart fuldstændig fortrængt af den offentlige skole, vore privatskoler er lukkede, og man forbyder os at lade vore børn undervise i kongerigske skoler. Disse sørgelige skoleforhold må ganske naturligt opfordre alle danske forældre til af al kraft at værne om den rest af dansk, der endnu er tilbage i folkeskolen, til at tage energisk fat på dansk undervisning i hjemmene, og til i så stor udstrækning som muligt at sørge for ungdommens undervisning i dansk, efter af skolepligten er ophørt.

En forening, som kan lede, spore og støtte arbejdet i disse retninger, vil efter vor mening kunne gøre et velsignelsesrigt arbejde og danne et betydningsfuldt led i den nationale forsvarskamp, der er bleven os påtvungen."

Opråbet var underskrevet af 64 kendte mænd, hvoraf over halvdelen var fra vesteregnen, heraf 12 fra den nuværende Skærbæk kommunes område. Desuden af enkelte landsdelskendte fløjfigurer som rigsdagsmand Gustav Johannsen fra Flensborg, Vælgerforeningens formand, slagter og kreaturhandler J.P. Reimers fra Sønderborg og gårdejer Peder Skau, Bukshave (Laurids Skaus bror), samt naturligvis H.P.Hanssen, der den gang var journalist i Sønderborg.

Denne sidste havde i øvrigt lagt megen vægt på, at initiativet helt klart udgik fra vesteregnen - derfor overvægten af underskrifter herfra -, og at stiftelsesmødet skulle finde sted herude. Det meste af den danske arbejde var nemlig koncentreret længere østover, og han forudså, at dannelsen af Skoleforeningen kunne være med til at aktivere danskheden i Vestslesvig.

Der var dog også kritiske røster. Landdagsmand Hans Lassen fra Lysabild på Als mente, at en særlig skoleforening blot ville sprede kræfterne. Man burde i stedet samle sig omkring Vælgerforeningen og Sprogforeningen. Redaktør Jens Jessen - senere Gustav Johannsens efterfølger som rigsdagsmand - var på samme linje og vendte sig i to artikler i »Flensborg Avis« imod tanken om en skoleforening. Den første artikel sluttede med følgende salut: »Over for de mange ansete navne under indbydelsen kunne man fristes til den bemærkning, at det måske ville være nok så heldigt, om nogle af vore bedste mænd ville betænke sig lidt mere, inden de lægger navn til et foretagende, der vel i og for sig kan være godt nok, men som burde underkastes en alvorlig prøvelse og overvejelse, inden det får lov til at starte.« $\mathrm{Da}$ foreningen havde vist, hvad den ville og formåede, svingede Jens Jessen dog helt om og støttede Skoleforeningen af al magt.

Det stiftende møde på Åblings Hotel indledtes af Jens Petersen Jensen, som opridsede formålet med foreningen, hvorefter H.P.Hanssen i et foredrag 
redegjorde nærmere for de tanker, som initiativtagerne havde gjort sig. Derefter opfordrede frimenighedspræst L.B.Poulsen fra Bovlund i en humoristisksarkastisk tale til at støtte initiativet, og gårdejer J.N.H.Skrumsager fra Københoved gjorde det samme, idet han glædede sig over "den fortrøstning, man nærede til sagen herude på vestkysten, hvor man ellers havde ord for at tage sig en middagslur for meget. « Dette fik Thyssen Hansen fra Randerup, der ellers havde været betænkelig, men nu gik ind for sagen, til at replicere: „Vi stakkels vestboer skulle have ord for at være rolige og søvnige, nå, det var da godt, man ville vedgå, at vi var danske!«, hvilket vakte ikke ringe munterhed. En enkelt røst, cand.phil. Jacobsen fra Brøns, vendte sig imod tanken, men ved afstemningen gik alle tilstedeværende på nær seks ind for dannelsen af foreningen, hvorefter man gik over til at vedtage lovene og vælge bestyrelsen.

Lovenes paragraf 1 . (formålsparagraffen) lyder: „Foreningens formål er at fremme folkeoplysningen, navnlig ved på lovlig måde at drage omsorg for børnenes og ungdommens undervisning på modersmålets grund.«

Til bestyrelsen valgtes femten mænd, bl.a. H.P. Hanssen (der nu sad i bestyrelsen for alle tre landsdelsdækkende nationale foreninger), Gustav Johannsen og pastor L.B.Poulsen. Fra vesteregnen blev følgende valgt, alle gårdejere: A.P.Lund, Ballum-Rejsby, H. Jepsen, Rørkær, Jens P. Jensen, Lovrup og Chr. Thygesen, Skærbæk. Jens Petersen Jensen blev formand og A.P. Lund næstformand, mens Hinrich Thomsen, Roost, blev sekretær og kasserer. I de følgende år var det Jensen og - især - Thomsen, der bar slæbet med at få foreningen til at »køre«.

Hinrich Thomsens søn, senere amtslæge, dr. med. H. Lausten Thomsen, skrev 50 år senere (1942) om dette forretningsudvalg: "... tre vestslesvigske gårdmænd, yderst forskellige $i$ lynne og tankesæt, men lige optaget af det arbejde, der nu lå for, at skaffe ungdommen dansk oplysning og knytte den til dansk tankegang. I de første år holdt dette forretningsudvalg en række møder i Tønder, Brede og Løgumkloster. Senere blev de holdt hjemme, hyppigst i Thomsens hjem i Roost. I disse møder var Jensen den iltre, Lund den betænkelige og Thomsen den fornemme og korrekte; men hverken Lunds alvor eller Thomsens forretningssans kunne stå for Jensens glade og tit højst uvedkommende bemærkninger i de alvorligste og betydningsfuldeste forhandlinger, og disse endtes altid i fuld enighed. $/$

Lausten Thomsen fortsætter: "I grunden var den opfattelse, der lå til bunds for disse tre mænds arbejde, højst forskellig, hvor enige de end var i selve deres danskhed og i ønsket om at hjælpe sønderjysk ungdom. Jensen stod fra først af den danske folkehøjskoles gerning nærmere end de to andre. A.P.Lunds interesse var mere kirkeligt end kristeligt betonet, medens det for Thomsen først og fremmest gjaldt om at hjælpe de unge til at læse og skrive 
modersmålet.« Det var et stort arbejde, de tre mænd havde påtaget sig, og for især Jensen og Thomsen betød det timer dagligt ved skrivebordet.

De prøjsiske myndigheder søgte naturligvis at lægge foreningen hindringer i vejen, bl.a. anvendte man en politiforordning, som forbød "ulovlig kollekt«, d.v.s. indsamling af kontingent hos ikke-medlemmer, f.eks. hos folk, som nok ville støtte foreningen, men som ikke ønskede deres navn på medlemslisten, der skulle afleveres og a jour-føres til myndighederne. Flere lokale tillidsmænd, bl.a. P.P. Buch i Melby ved Skærbæk, blev af de lokale amtsforstandere idømt bøder, i Buchs tilfælde 30 mark, som retten i Toftlund dog nedsatte til 20 mark.

Arbejdet i Skoleforeningen var krævende og meget tidsrøvende, men for alle var der tale om et ulønnet tillidshverv. Herom skrev Jens Jessen i et brev til Hinrich Thomsen i Roost, 1896: „Skoleforeningen tiltaler jo mig så særdeles, fordi den uden bihensigter ledes ikke af erhvervspolitikere, men af mænd, der udelukkende arbejder af iver for sagen. Det var derfor mere end et mundsvejr, når jeg forleden udbragte et leve for forretningsudvalget. Jeg nægter ikke, at jeg også synes, formanden, Jensen i Lovrup, er en meget tiltalende person.«

Hvert år sendtes adskillige unge til de kongerigske høj- og efterskoler, og de tyske - prøjsiske - myndigheder blev efterhånden mere og mere betænkelige ved, hvad der skete. I december 1896 skrev »Hamburger Nachrichten« (den tidligere rigskansler Bismarcks talerør): „Betragtet fra det tysk-nationale standpunkt bærer denne antityske "skoleforening" en uhyre fare i sig. Den er en indretning, der $\mathrm{i}$ fremtiden vil være langt mere hindrende for tyskhedens udbredelse end hidtil de nordslesvigske presseorganer, agitatorer og rumleforeninger af den forskelligste slags har varet. Man har i tysk-nationale kredse ofte mødt den vildfarelse, at danskheden i det nordlige Slesvig ville uddø med det nuværende slægtled. Dette er en vældig vildfarelse. Danskheden vil netop ved en opvoksende ungdom, der er blevet dresseret på danske "afretningsinstitutter", få en uhyre forstærkning, så meget mere som de "unge« er langt mere rørige på sig end de mådeholdne "gamle«. Og tallet på de i Danmark dresserede unge protestmænd øges i truende grad. Medregnes de 164 unge nordslesvigere, som i dette vinterhalvår af "Skoleforeningen« holdes på forskellige danske institutter, har foreningen i de syv (halv)år, den har bestået, ladet uddanne ikke mindre en 828 nordslesvigske børn i Danmark.« Det var da trods alt en anerkendelse!

I juni 1897 fik enkefru Stamp i Ullerup besked på at tage sin datter Karen hjem fra Hejls ungdomsskole, da det var "kommet til formynderrettens kundskab, (...) at børnenes opdragelse i de danske skoler ikke ledes i tysk national ånd, men at de tværtimod der ophidses imod tyskheden.« Derfor kunne "umyndige børns ophold på danske skoler ikke tåles«, og hvis fru Stamp ikke 
tog datteren hjem, ville hun blive idømt en bøde på 100 mark. Da hun ikke rettede sig efter denne henstilling, idømtes hun bøden og fik en yderligere frist på 14 dage med trussel om endnu en bøde, denne gang på 150 mark.

En anke blev afvist af landsretten i Flensborg, som i sin begrundelse skrev, at hun "ved at udsætte sin datter for denne fare « - daniseringen - handlede imod sin afdøde mands vilje og ønsker (!). Han var, skrev retten, windvandret fra provinsens sydlige del, var bestemt tysksindet og modstander af de danske bestræbelser.« Opholdet i Hejls var således mimod både statens interesser, hendes faders intentioner og - især til åbenbar skade for barnet selv!«

Retten fortsætter: "Indpodningen af antitysk ånd plumrer det pietetsfulde minde om den tysksindede, afdøde fader og gør tilmed datteren utilfreds og fjendtlig imod den stat, der er hendes hjem, hvis undersåt hun er, og i hvilken hun efter al sandsynlighed er anvist til senere at skulle leve. « Fru Stamp ankede til kammerretten i Berlin, som i december 1897 ophævede landsrettens dom, hvorved også bøderne faldt bort.

Også Jens P. Jensen fik en lignende sag på halsen. Han var nemlig formynder for drengen Jens Keller fra Lovrup, og amtsdommeren i Logumkloster skrev til ham, at "under de foreliggende politiske forhold må det aldeles sikkert antages, at de unge mennesker $i$ helt danske omgivelser må bukke under for den tyskfjendtlige indflydelse, der uafbrudt øves på dem.«

Man mærkede, at Ernst Mathias von Köller i aug. 1897 var blevet overpræsident i Slesvig, d.v.s. den øverste embedsmand i provinsen Slesvig-Holsten. Det var hans mål ved hjælp af hårdhændet pression at kue danskheden $\mathrm{i}$ Nordslesvig, og til den ende skyede han og de fleste af hans embedsmænd intet middel.

Således udsendte den »landsfaderlige« landråd (amtmand) von Tschirschnitz i Sønderborg i december 1898 et »fortroligt« cirkulære til amts- og kommuneforstanderne i Sønderborg kreds (amt), hvori de fik besked om at meddele de forældre i deres distrikt, som havde børn i kongerigske skoler, at alle danske undersåtter i kommunen ville blive udvist, hvis ikke børnene blev trukket hjem senest 20. december, d.v.s. samtidig med at juleferien begyndte.

Hvad skulle forældrene gøre? Skulle de bøje sig eller sige nej og dermed risikere, at deres naboer og bysbørn blev jaget fra hus og hjem?

Ledelsen af de nationale foreninger trådte sammen, og Vælgerforeningen, det danske "parti«, udsendte en skrivelse, underskrevet af 254 af landsdelens kendteste og mest indflydelsesrige mænd: "Den trussel, hvormed man søger at skræmme nordslesvigske forældre fra at lade deres voksne børn søge danske skoler, er af den natur, at den i al fremtid vil kunne anvendes til at fremtvinge bestandig nye indrømmelser, bestandig større eftergivenhed, bestandig dybere underkastelse. Der gives ikke nogen som helst statsborgerlig rettighed, som man ikke kunne søge at fratage os på denne måde.« 
„Vi overser ikke den fare, som truer vore medborgere, « fortsatte udtalelsen. »Men lige så stor vor deltagelse med dem er, lige så stor er vor harme over, at man vil fratvinge os vore lovlige rettigheder ved trusler med at føre landsforvisningens ulykke over vore brødre, uden at disse har forset sig i nogen retning. Vi gør derfor den kraftigste indsigelse imod de prøjsiske myndigheders adfærd imod os. Til denne indsigelse føjer vi den ubetingede forsikring, at vi ingenlunde vil lade os kue af slige trusler.« Og da juleferien oprandt, blev de unge på skolerne $\mathrm{i}$ kongeriget.

Derudover skete intet. Ikke én familie, ikke én person blev udvist.

"Den nordslesvigske befolknings solidaritet havde stået sin prøve på en måde, som den prøjsiske tvangspolitiks ophavsmænd ikke havde ventet, « skrev Skoleforeningens senere sekretær, Anders Lebeck, i 1912.

Samme år - i februar 1898 - havde Jens Petersen Jensen udsendt en opfordring til forældrene om at sende de unge på kongerigske skoler. Hvert år drager mange derhen, skrev han, »men det var ønskeligt, om tallet kunne øges, thi det er dog kun en mindre part af alle de unge, der årligt ved konfirmationsalderen går ud af skolen, som kommer på de kongerigske skoler, og alle trænger jo hårdt dertil.« Derfor vil han alvorligt opfordre alle forældre til at »sætte alle små hensyn og betænkeligheder, som kunne træde hæmmende i vejen, til side« og sende så mange unge som muligt nordpå. "Skulle pengespørgsmålet være et af de hensyn, som kunne træde hæmmende i vejen, så vil Skoleforeningen, når der er værdighed og bevislig trang til stede, med glæde træde hjælpende til, så vidt dens midler rækker,« slutter han og oplyser, at henvendelse skal ske til »foreningens sekretær, gårdejer $\mathrm{H}$. Thomsen, Roost pr. Arrild.«

Skoleforeningens elever

I årene 1894-1913 blev der fra den nuværende Skarbæk kommunes område sendt følgende antal elever til skoler $\mathrm{i}$ kongeriget ved Skoleforeningens mellemkomst (inddelt efter de prøjsiske småkommuner fra før 1920). Fra hele Nordslesvig var tallet i samme periode 5673 .

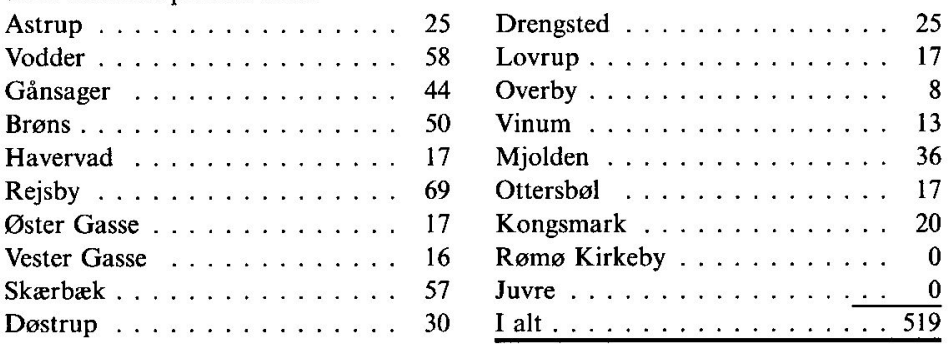



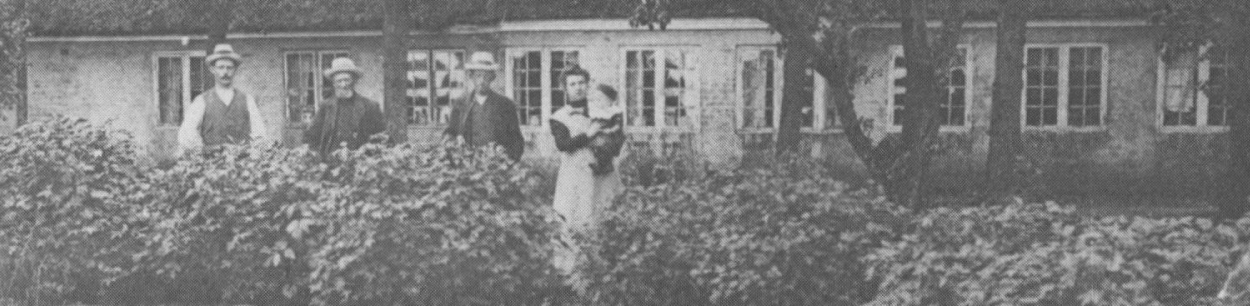

Jens Petersen Jensens gärd i Lovrup. Fra venstre gdr. Jens Keller, Jens Petersen Jensen, Jens Oksen Jensen (hans son) og Marie Roost Jensen (g.m. J.O.J.) med Jens P. Jensen (barneharn) pă armen. Foto 1912 i Skarbakegnens Museum.

\section{Foreningsarbejdets pris}

Imidlertid havde det store uegennyttige arbejde, de mange møder og stor gæstfrihed i forbindelse med sådanne møder på gården i Lovrup tæret på Jensens økonomi, så meget mere som han kun i ringe grad selv kunne være hjemme og passe gården. Han søgte at redde sig ud af klemmen ved at sælge jord fra, men det var ikke nok, og i 1899 var han kommet derhen, at han måtte vælge, om det skulle være gården eller foreningen. For dog ikke at gå helt økonomisk under måtte han samme år meddele, at han trådte tilbage som formand af "personlige grunde«, altså for at søge at redde stumperne.

Hans efterfølger blev Andreas Thyssen Hansen fra Randerup, som derefter var formand til 1910, da han afløstes af endnu en vestslesvigsk gårdejer, den kun 30-årige Hans Jefsen Christensen fra Høgsbro, der beklædte posten i mere end en menneskealder. Hinrich Thomsen fortsatte som kasserer og delvist som sekretær under Thyssen Hansen, men afløstes 1911 af redaktør Anders Lebeck.

Selv om Jens Petersen Jensen var trådt ud af Skoleforeningens ledelse, fulgte 
han med stor interesse arbejdet, så længe han levede. Det lykkedes ham også at bringe gården så nogenlunde på fode igen, så han efter sin kones død $\mathrm{i}$ 1908 , hvor han selv nærmede sig de 70, kunne overdrage den til sønnen Jens Ocksen Jensen, der drev den til 1926.

Hans Petersen skriver om ham i »Sprogforeningens Almanak «, 1924: »Det var ikke ualmindeligt, at byens børn kaldte ham "Bedstefar", medens "Jens Peesen « var hans almindelige navn der på egnen. I et selskab var han, selv $\mathrm{i}$ de senere år, livlig og munter. På sit vesterbomål holdt han ved slige lejligheder korte, men vittige taler, ikke sjældent på rim."

Et vidnesbyrd om denne evne blev fremdraget for nogle år siden, da man restaurerede Døstrup kirkes spir. Man fandt da et stykke papir med følgende indhold:

"Dette lille digt indlægges i kuglen på den ny fløjstang, for når den engang i fremtiden atter nedtages, kunne vidne den dalevende slægt om, hvordan forholdene for tiden ere under prøjserherredømmet.

Seks og tyve år nu forløbne er under Prøjsens herredømme.

Men ej de har vundet vor kærlighed, det må vist enhver indrømme.

Med magt de os nu fortyske vil, med magt de vil os sproget fratage, men aldrig de skal få held dertil, thi endnu lever den gamle af dage. Retssproget er udelukkende tysk, i skolen vore børn det samme kun lære, men vor sind og hu kun ene er jysk, og vi betakker os for den ære. $\mathrm{Vi}$ ere og ville forblive danske, og som danske vi behandles vil. Dette Krygers ord vi hylde ganske og rigtig af hjertet slutte os til.

Bestandig vi håbe at komme tilbage en gang i tiden til Danmark igen.

Derfor under trykket vi ej forsage, men stole på Gud, som er ret og sandheds ven. $\mathrm{Ja}$, gid atter det skilte snart føjer sig sammen, det give den almægtige Gud. Amen.

Lovrup, den 13. august 1890.

Jens P. Jensen.« 


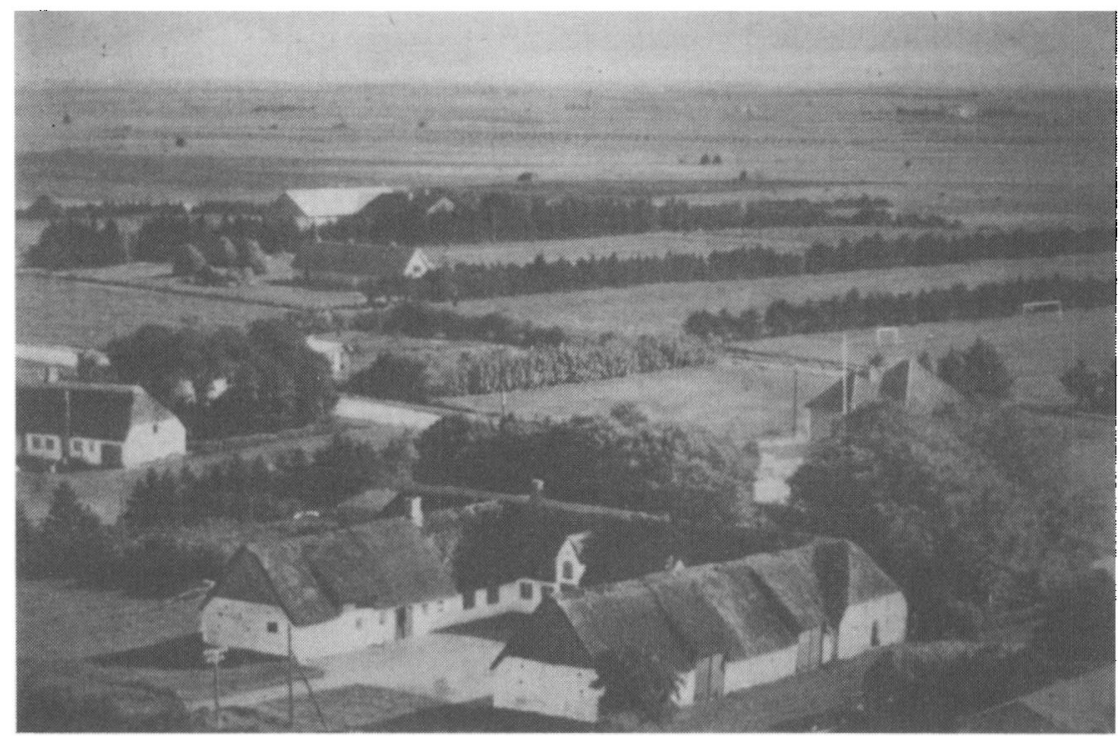

Jens Petersen Jensens gård i Lovrup. I dag ejes ejendommen Poulskrovej 4, Lovrup af Thomas Hyhschmann. Foto ca. 1930 i Skarbakegnens Museum efter original på gården.

Foruden digtet fandtes et stykke papir med følgende oplysninger om egnen og tiden:

»Priserne på landbrugsprodukter er for tiden således: For rug, td. 200 pund, 16,00 M. Byg: 14,00 M. Havre, 150 pund: 13,00 M. Boghvede, 200 pund: $12,00 \mathrm{M}$. En almindelig god kælveko $300 \mathrm{M}$. En $2 \frac{1}{2}-3$ års okse $300 \mathrm{M}$. Svin pr. 100 pund levende vægt $40 \mathrm{M}$. Får pr. pund levende vægt $0,26 \mathrm{M}$. En god 3 års hest 7-800 M.

Løn til en karl for 1 år 250 til $300 \mathrm{M}$. I sommer haves en meget god høog kornavl, men lidt besværlig på grund af temmelig megen regn. $1888 \mathrm{og}$ 1889 blev vestbanen anlagt og åbnet i februar 1889. Fra Døstrup blev personbefordringen åbnet den 10 . januar 1890. Godstrafikken bliver åbnet $\mathrm{i}$ den nærmeste fremtid.

Sundhedstilstanden her i sognet er for tiden god. Der er mindst 6-7 personer over 80 år, alle åndsfriske.

På grund af at denne skrivelse ikke kom til stede, da fløjstangen blev opsat, bliver samme indlagt $i$ en flaske under blytaget $i$ spidsen af tårnet.

J.P. Jensen - N.O. Aabling - M.H.Petersen.

Efter-skrift: Her i sognet er for nylig oprettet en Goodtemplarloge, ikke just fordi befolkningen er hengiven til drik, endskønt de fleste nok kan drikke en 
lille kaffepuns, men formålet er at indskrænke drikkeriet, som mange steder er ved at tage overhånd.«

Om Jens Petersen Jensens forhold til vestbanen fortæller iøvrigt det tidligere nævnte udaterede udklip fra (vistnok) »Jydske Tidende«:

"Linjeføringen havde været til livlig drøftelse i sognet. Der var to muligheder: For det første skulle banen føres fra Tønder over Løgumkloster til Skærbæk og videre nordpå. Den anden gik ud på, at banen skulle gå over Bredebro øst om Døstrup og videre. Som bekendt blev dog ingen af disse to planer gennemført, og en tredje linjeføring blev en realitet. Peder (d.v.s. J.P.) Jensen strittede længst muligt imod, da han var modstander af at få banen for tæt til byen, da han ikke ønskede en tilstrømning af tyske embedsfolk, og man ønskede heller ikke, at toget skulle holde i Døstrup.

Da det viste sig, at banen havde stor betydning for de forskellige byer, fortrød man snart den negative indstilling og fik efter forhandlinger toget til at standse i Døstrup, men Døstrup station blev aldrig udbygget $\mathrm{i}$ lighed med stationerne i Visby og Brøns.«

Ved sin halvfjerdsårsdag i 1911 blev Jens Petersen Jensen genstand for stor hyldest. Han levede $i$ endnu tolv år og oplevede såvel 1. verdenskrigs ulykke som Genforeningens glæde. Kort efter Sønderjyllands tilbagekomst til Danmark modtog han ridderkorset, og den 4. juli 1923 døde han, 82 år gammel.

\section{KILDER}

Hans Lund (red.): Sonderjydsk Skoleforening 1892-1942. Kolding, 1942.

Hans Petersen: Jens Petersen Jensen. Sprogforeningens Almanak, 1924.

Udklip fra "Vestslesvigsk Tidende“ (?) 1898, og "Jydske Tidende“ (?), udateret.

Upublicerede papirer, udlànt af J.P.Jensen, Bov, og Th. Hybschmann, Lovrup. 